\title{
DIEGO GÓMEZ-VENEGAS
}

DIEGO GÓMEZ-VENEGAS

UNIVERSIDAD DE CHILE

DEPARTAMENTO DE DISEÑO

SANTIAGO DE CHILE

diegogomez@uchilefau.cl

\section{DISEÑO EXPERIMENTAL COMO PRÁCTICA ARQUEOLŌGICA}

DISEÑA 12 I ENERO 2018 I ISSN: 0718 8447 I ARTÍCULO DE INVESTIGACIÓN ORIGINAL

RECEPCIÓN: 29 DE SEPTIEMBRE 2017 I ACEPTACIÓN: 31 DE OCTUBRE 2017

CÓMO CITAR ESTE ARTÍCULO:

Góm EZ-VENEGAS, D. (2017). Diseño experimental como práctica arqueológica. Diseña (12), 150-171.

DOI: $10.7764 /$ disena.12.150-171

p.

DISEÑA 12 I JANUARY 2018 I ISSN: 0718 8447 I ORIGINAL RESEARCH ARTICLE

RECEPTION: SEPTEMBER 29, 2017 I ACEPPTANCE: OCTOBER 31, 2017

HOW TO CITE THIS ARTICLE:

Сóm EZ-VEnEGAS, D. (2018). Experimental Design as Archeological Practice. Diseña, (12), 150-171.

DOI: $10.7764 /$ disena.12.150-171

TRANSLATION: JOSÉ MIGUEL NEIRA

\section{EXPERIMENTAL DESIGN AS ARCHEOLOGICAL PRACTICE}

DIEGO GÓMEZ-VENEGAS UNIVERSIDAD DE CHILE DESIGN DEPARTMENT SANTIAGO, CHILE diegogomez@uchilefau.cl 


\section{Resumen}

Este texto presenta una aproximación al diseño entendida como práctica arqueológica; esto es, una actividad indagatoria que - desde las teorías foucaultianas-quiere desentrañar los órdenes epistémicos imbuidos en las máquinas, para dar cuenta de los modos de conocer que ellas instalan en la cultura y la sociedad. Se introduce así la arqueología del saber como aproximación investigativa en el ámbito de las ciencias humanas y, luego, como metodología de análisis de la cultura en el campo de los estudios de medios, a través del trabajo de Friedrich Kittler y Wolfgang Ernst. Posteriormente se comenta un proyecto de diseño experimental —una tesis de la Universidad de Chile- para ejemplificar los modos en que dicha perspectiva transforma el quehacer del diseño y sus categorías disciplinares. Finalmente, el texto esboza una propuesta metodológica para este diseño, proyectando, además, un contexto institucional donde esta propuesta pueda desarrollarse en plenitud.

Palabras clave: Diseño experimental, arqueología de medios, máquinas, Friedrich Kittler, Wolfgang Ernst

\begin{abstract}
This article presents an approach to design which is understood as an archaeological practice; that is, an inquiry that - from the Foucauldian theoriesseeks to unravel the epistemic orders embedded in the machines; to show the modes of knowing they install in culture, and in society. Thus, the archaeology of knowledge is introduced as investigative approach within the realm of human sciences and, then, as a methodology for the analysis of culture in the field of media studies, through Friedrich Kittler's and Wolfgang Ernst's ideas. Then, an experimental design project, a thesis of the Universidad de Chile, is commented on to exemplify the modes in which such perspective transforms the activity of design and its disciplinary categories. Finally, the text draws a methodological proposal for this design, mapping out an institutional context where this proposal can be developed in full.
\end{abstract}

Keywords: Experimental design, Media archaeology, Machines, Friedrich Kittler, Wolfgang Ernst

\begin{abstract}
Diego Gómez-Venegas
Diseñador, Universidad de Chile. Master of Fine Arts in Design Media Arts, Universidad de California Los Ângeles. Profesor asistente del Departamento de Diseño en la Facultad de Arquitectura y Urbanismo de la Universidad de Chile. Crea e investiga sobre aparatos técnicos, sus agencias y condiciones epistémicas. $\mathrm{Ha}$ recibido becas de la Comisión Fulbright y de la Comisión Nacional de Investigación Científica y Tecnológica de Chile. Entre sus últimas publicaciones destacan CyberSyn: Hacia una arqueología de los lenguajes mediales y visuales (en co-autoría con Manuela Garretón, Polígrafa, 2017) y "Naturaleza Ex-novo: aparatos agonistas para el rediseño de la naturaleza y sus márgenes en Chile" (junto a A. Âlvarez Dumont, Kepes, vol. 14, n. ${ }^{\circ} 16$ ).
\end{abstract}

\begin{abstract}
Diego Gómez-Venegas
Designer, Universidad de Chile. Master of Fine Arts in Design Media Arts, University of California, Los Angeles. Assistant Professor in the Department of Design at the School of Architecture and Urbanism at Universidad de Chile. He creates and researches technical devices, their agencies and their epistemic conditions. He has received scholarships from the Fulbright Commission and the National Commission for Scientific and Technological Research of Chile. Some of his latest publications include CyberSyn: Hacia una arqueología de los lenguajes mediales y visuales (with Manuela Garretón, Polígrafa, 2017) and Naturaleza Ex-novo: aparatos agonistas para el rediseño de la naturaleza y sus márgenes en Chile (with A. Álvarez Dumont, Kepes, vol. 14, $\mathrm{N}^{\circ}{ }_{16}$ ).
\end{abstract}


A través de este texto intentaré conceptualizar y ejemplificar una aproximación al diseño - a su problematización teórica y a su práctica creativa- que se sustenta en una idea de experimentalidad. Tal noción debe mirarse, sin embargo, bajo una triple distinción.

Primeramente, y en lo general, el término experimentalidad debe ubicarse más cerca de los espacios metodológicos propios de las artes y las humanidades que de concepciones ligadas a las ciencias e investigaciones experimentales; es decir, se trata, más bien, de una experimentalidad que invita a descentrar los entendimientos disciplinares normativos para dirigir así la atención hacia los bordes intersticiales de dichas áreas - donde las conceptualizaciones de tales normas podrían ponerse en cuestión e, incluso, derrumbarse-. En este sentido, no se trata tanto de un modelo sistemático de experimentos con variables y procedimientos cuidadosamente controlados, como ocurre, por ejemplo, cuando se procede apropiadamente en el contexto de una investigación aplicada — aunque también sea posible partir de este espacio de experimentación, para moverse luego hacia esa otra experimentalidad-.

En segundo lugar, y ya en un espacio más específico, esta experimentalidad busca superar nociones estáticas sobre el diseño. Por lo mismo, cuando hablo de diseño en este texto, no apunto a una profesión o práctica creativa específica, sino a todas ellas como un conjunto

\section{TOWARDS AN EXPERIMENTALITY FOR AN ARCHEOLOGY}

Through this text I will try to conceptualize and exemplify an approach to design - to its theoretical problematization and to its creative practice-based on an idea of experimentality. This notion, however, must be analyzed under three distinctions:

Firstly, and in general, the term 'experimentality' should be closer to the methodological spaces of the arts and humanities than to notions linked to experimental sciences and research; that is to say, it is rather an experimentality that encourages one to direct attention towards the interstitial edges of the normative disciplinary understandings instead to their center. It is on the edges where the conceptualizations of such norms can be questioned or even dismantled. In this sense, it is not necessarily about a systematic model of experiments with variables and carefully controlled procedures (as tends to be the case in applied research) - although it is also possible to start from this experimental space and then move on to that other experimentality.

Secondly, and more specifically, this experimentality seeks to overcome static notions of design. Therefore, when I talk about design in this text, I do not refer to a specific creative profession or practice, but rather to all of them as a whole, in which the action of design, as a common procedural 
en el cual la acción de diseñar atraviesa, en tanto eje procedimental común, una vocación plural para la configuración material de la cultura.

Por último, la tercera distinción sobre la noción de experimentalidad refiere al ejercicio de enviar una sonda que atraviese y examine las múltiples capas de las culturas pasadas y contemporáneas, con el propósito de desentrañar a partir de ellas los órdenes epistémicos que lentamente se han sedimentado y acumulado para configurarlas; en otras palabras, esta tercera distinción refiere a una práctica arqueológica.

Tal aproximación requiere, entonces, un breve desarrollo sobre la noción de arqueología para clarificar qué se quiere decir aquí cuando se la nombra. Comencemos por recordar que con sus obras Las palabras y las cosas (1966/2008) y La arqueología del saber (1969/2010), el filósofo francés Michel Foucault introdujo un método de análisis crítico sobre la construcción del conocimiento, el cual se caracterizó por estudiar el espacio material que, él entendió, ha estado al centro de las culturas de occidente: el archivo. Tal lugar, constituido por series de documentos escritos, corresponde no sólo a un mero repositorio, sino más bien al ordenamiento particular y fundamental del saber: su episteme.

Dicho método, la arqueología, se caracteriza por aproximarse a estos documentos para discernir los modos en que el mencionado saber es configurado, para entender así las estructuras y formas de articulación a través de las cuales dicho saber condiciona, luego, los entendimientos y modos de conocer de los individuos. En otras palabras,

axis, goes through a plural vocation for the material configuration of culture.

Finally, the third distinction on the notion of experimentality refers to the exercise of using a probe that traverses and examines the multiple layers of past and contemporary cultures, with the purpose of unraveling the epistemic orders that have slowly settled and accumulated to configure them; in other words, this third distinction refers to an archaeological practice.

Such an approach thus requires a brief development of the notion of archeology, such as to clarify what is meant when it is referred to here. We can start by recalling that through his works The Order of Things (1966/2008) and The Archeology of Knowledge (1969/2010), the French philosopher Michel Foucault introduced a method of critical analysis of the construction of knowledge, as characterized by its study of the material space that, as he understood it, has been at the center of western cultures, namely, the archive. Such a place, constituted by series of written documents, is not only a mere repository, but rather the particular and fundamental ordering of knowledge: i.e. its episteme.

This method, archeology, is characterized by utilizing these documents in order to discern the ways in which the said knowledge is configured, thus understanding the structures and forms of articulation 
la arqueología foucaultiana se convirtió así en un dislocamiento clave sobre el pensamiento antropocéntrico clásico, pues ella parte, por el contrario, de la premisa de que es el ordenamiento intrínseco del archivo el que determina el pensar de los sujetos, y no al revés, como hasta entonces $-\mathrm{y}$ aun todavía - se señalaba.

En esta misma ruta de análisis surgirá, algunas décadas más tarde, la arqueología de medios. Siendo un campo aún en desarrollo y relativamente desconocido para el establishment académico y creativo, éste constituye, sin embargo, un espacio clave para rearticular las nociones y entendimientos establecidos hegemónicamente sobre el diseño y sus prácticas asociadas.

Acercarse a este campo implica probablemente revisar parte del trabajo del pensador alemán Friedrich Kittler, quien tomó el trabajo de Foucault para expandirlo más allá del archivo de documentos escritos, llevándolo hasta los medios (Kittler, 1992); es decir, hasta los aparatos tecnológicos que transmiten, procesan y almacenan la información que hoy sostiene a las culturas. Para Kittler, luego del giro post-histórico, los documentos escritos no son suficientes para comprender los órdenes epistémicos que definen lo contemporáneo y, alternativamente, el método arqueológico debe expandirse hasta el espacio de los medios técnicos para vislumbrar y comprender la constitución del saber hoy (Zerené, 2017, pp. 101-104).

Por lo mismo, Kittler estudió complementaria y detenidamente el

through which that knowledge determines how individuals understand and know. In other words, the Foucauldian archeology became a key dislocation in classical anthropocentric thought, because it is based on the premise that it is the intrinsic ordering of the archive that determines the thought of the subjects, and not the other way around, as it was previously believed.

A few decades later, media archeology would emerge along this same path. Still in development and relatively unknown to the academic and creative establishment, this field constitutes, nevertheless, a key space to re-articulate the hegemonically established notions and understandings about design and its associated practices.

Approaching this field is likely to involve reviewing part of the work of the German thinker Friedrich Kittler, who took Foucault's work and expanded it beyond the archive of written documents, in order to encompass the media (Kittler, 1992): that is, the technological devices that transmit, process and store the information that sustains cultures today. For Kittler, after the post-historical turn, written documents are not sufficient for understanding the epistemic orders that define the contemporary, Alternatively, the archaeological method must expand into the area of technical media in order that the constitution of knowledge to- 
Figura 1: Esquema conceptual Kittler-Lacan. Dibujo: El autor (redibujado). trabajo del psicoanalista francés Jacques Lacan en lo relativo a las conexiones entre el pensamiento humano y las esferas de la técnica (Lacan, 1953-1954/2008). Allí encontró, en la triada de lo Real, lo Simbólico y lo Imaginario elaborada por el psicoanalista, una matriz para profundizar en los procesos de transmisión, procesamiento y almacenamiento que, él sostiene, constituyen la base del comportamiento y alcance de los medios técnicos (Figura 1). De este modo, a partir del modelo conceptual de Lacan llamado Estadio del espejo — donde se relata el momento en que un niño pequeño se encuentra con un espejo y, al ver su reflejo allí, a diferencia de otros mamíferos, reconoce, y a la vez construye, la imagen que tiene de sí-, Kittler desarrolló una teoría que busca desentrañar el modo en que los medios técnicos, como una cámara fotográfica, capturan y transmiten las señales de lo Real, procesando

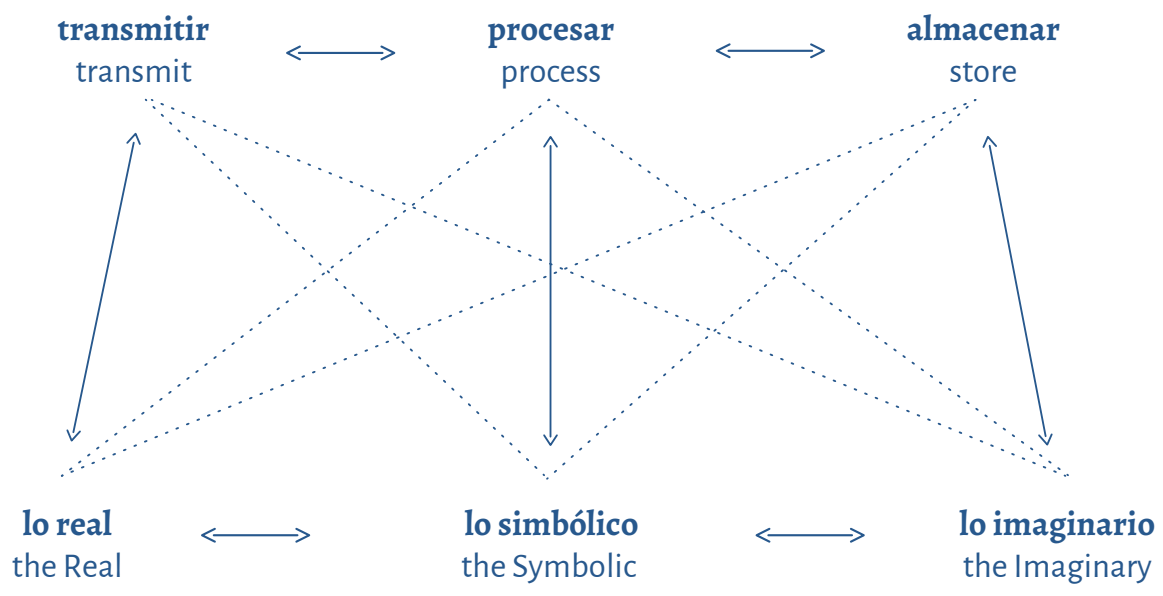

Figure 1: Kittler-Lacan conceptual outline. Illustration: The Author (redrawn). day be understood (Zerené, 2017, pp. 101-104).

For the same reason, Kittler studied the work of the French psychoanalyst Jacques Lacan in a complementary and careful manner in relation to the connections between human thought and the spheres of technology (Lacan, 1953-1954/2008). In the triad of the Real, the Symbolic and the Imaginary, the psychoanalyst developed a matrix to delve into the processes of transmission, processing and storage that, he argues, constitute the base of the behavior and the scope of technical media (Figure 1). In this way, from Lacan's conceptual model called The Mirror Stage (the moment in which a small child sees his reflection in a mirror, and unlike other mammals, thereby recognizes and builds the image he has of himself), Kittler developed a theory that seeks to unravel the way in which technical media, such as a camera, capture and transmit the signals of 
1 Es importante aclarar que en este ámbito, el de la arqueología de medios de Kittler y Ernst, lo Simbólico debe entenderse como el lugar gobernado por sistemas de símbolos, $\mathrm{y}$ no como el espacio de las figuras retóricas, tal como señala el uso cotidiano. Así, con "lenguajes simbólicos" refiero a lenguajes escritos y numéricos y, por extensión, también a lenguajes técnicos, tecnológicos y materiales. luego éstas a través de lenguajes Simbólicos ${ }^{1}$ para generar, por último, la información que, una vez almacenada, (re)construirá lo Imaginario.

Para ponerlo en términos más simples: para Kittler, cualquier entendimiento que podamos tener de nosotros mismos, de nuestras sociedades y de nuestras culturas, responde finalmente a procesamientos de lenguajes maquínicos, almacenados en (y transmitidos por) los mismos medios técnicos; es decir, el archivo, el orden epistémico contemporáneo, sería consecuencia de, y estaría finalmente en, las máquinas mismas (Kittler, 1993/2017).

Gran parte de las teorías que Friedrich Kittler desarrollara hasta su muerte han encontrado eco y expansión en el trabajo del académico alemán Wolfgang Ernst, quien ahonda en la noción de archivo, señalando que la labor de la arqueología de medios es, precisamente, aquella de indagar en lo que él ha denominado tecnoepistemología; es decir, el conocimiento desarrollado por los mismos medios técnicos, conocimiento que, podría sostenerse, es al mismo tiempo resguardado por ellos (2012, pp. 55-73). Más aún, Ernst ha hablado de una arqueografía -o escritura del arché, del archivo-, argumentando que hoy más que nunca podemos observar que son las máquinas las capaces de llevar adelante la tarea arqueológica - y con ello el desarrollo de conocimiento- de modo autónomo, sin la asistencia de ser humano alguno (2012, pp. 55-73).

Al igual que Kittler, Ernst vio ya este fenómeno en el registro de

the Real, processes them through Symbolic languages, and finally generates the information that, once stored, will (re)build the Imaginary.

In other words, for Kittler, any understanding that we have of ourselves, of our societies and our cultures, finally responds to processes of machinic languages, stored in (and transmitted by) technical media themselves; that is to say, the archive - the contemporary epistemic order,-would be a consequence of, and in, the machines themselves (Kittler, 1993/2017).

Most of the theories that Friedrich Kittler developed during his life have found echo and expansion in the work of the Cerman academic Wolfgang Ernst, who delves into the notion of archive, noting that the work of media archeology is precisely to investigate what he has called techno-epistemology; that is, the knowledge developed by the very technical media, which, it could be argued, is at the same time protected by them (2012, pp. 55-73). Moreover, Ernst has spoken of an archeography (a writing of the arche), arguing that today, more than ever, we can observe that the machines are capable of carrying out the archaeological task, and developing knowledge from it, autonomously, without human assistance (2012, pp. 55-73).

Like Kittler, Ernst already identified this phenomenon in the capture 
señales sonoras que permitieron las máquinas fonográficas (2012, pp. 55-73), visualizando que dicha arqueografía ocurre con fuerza también hoy, tal vez de modo intensificado, en las tecnologías que procesan sistemas de símbolos, como el computador, y más particularmente a través de sus algoritmos; cuyo alcance -lo podemos ver, si queremos, cada día- no está solamente en la activación de procesos artificiales —al interior de las máquinas-, sino, más bien, en el levantamiento de información a través del reconocimiento de patrones en el campo de lo Real (Kittler, 1993/2017, pp. 148-151).

Esto da paso, por cierto, a una línea metodológica de fuerte carácter no-antropocéntrico, cuyo foco de interés estará precisamente en el estudio de los actores no-humanos y las redes de conocimiento que ellos puedan propiciar y, más aún, generar y expandir. En este punto, Ernst ha sido especialmente claro, procurando, además, esbozar lazos que permitan ver las coincidencias entre su pensamiento arqueológico y el desarrollo de ideas homólogas en campos tales como los estudios de ciencia y tecnología (s TS). Es así como Ernst ha señalado, por ejemplo, que «en contraste con la típica crítica tecnológica de la Escuela de Sociología de Frankfurt, el modelo del actor-red de Bruno Latour ha liberado a lo "social" de su limitado sentido antropocéntrico» (2016, p. 44). Dicho de otro modo, las redes de asociación entre actores humanos y no-humanos que el antropólogo francés Bruno Latour ha dibujado para redefinir el alcance de lo social (Latour, 2008a) encuentran en

of sound signals that allowed the development of phonographic machines (2012, pp. 55-73), visualizing that archeography is still in full force today. This may even be intensified in the technologies that process systems of symbols, such as the computer, and more particularly through their algorithms, whose scope (that is readily and easily ascertainable by anyone) is not only in the activation of artificial processes inside the machines, but rather gathering information through pattern recognition in the field of the Real (Kittler, 1993/2017, pp 148-151).

This leads on to a strongly non-anthropocentric methodological line, in which the focus of interest will be precisely the study of non-human actors and the networks of knowledge that they can promote, generate and expand. In this sense, Ernst clarifies this methodology, while attempting to develop connections that may lead to the discovery of coincidences between his archaeological thought and the development of homologous ideas in fields such as science and technology studies (STS). This is how Ernst has demonstrated for example, that "in contrast to the criticism of technology typical of the Frankfurt School of Sociology, Bruno Latour's actor-network model has liberated the 'social' from its limited anthropocentric meaning" (Ernst, 2016, p. 44). In other words, the networks of association between human and non-human actors that 
2 En una entrevista a Bruno Latour realizada junto al arquitecto Mario Marchant en 2014, y ante mi pregunta sobre si veía lazos entre su trabajo y las teorías arqueológicas hasta aquí discutidas, Latour señaló que aquello iba de algún modo en la misma dirección que su trabajo, sólo que bajo otra denominación (comunicación personal, 9 de noviembre, 2014). las máquinas, a través de la arqueología de medios de Kittler y Ernst, un actor específico, altamente agenciado y, por lo mismo, clave para comprender los acontecimientos sociales ${ }^{2}$.

En suma, entendamos entonces la arqueología, y específicamente la arqueología de medios, como un método que permite indagar en las cosas, en el campo de lo artificial, para trazar sus órdenes epistémicos; es decir, dar con los conocimientos específicos que ellas transmiten, procesan y almacenan, agenciando así, de paso, los entornos y actores a su alcance. Ahora bien, permítaseme, en el contexto de este texto, movilizar las nociones de "cosa" y "campo de lo artificial" — precisamente por lo señalado anteriormente- hacia la idea de máquinas; expandidas éstas más allá de la concepción usual que las sitúa en el ámbito de lo mecánico solamente, para visualizarlas, entonces, con un énfasis conceptual, en tanto máquinas escriturales, máquinas ópticas, máquinas fonográficas y máquinas simbólicas (Ernst \& CCAchannel, 2014), pues será de ese modo que podremos, en lo que sigue, esbozar sus capacidades de agencia y sus acciones de transmisión, procesamiento y almacenamiento de información y conocimiento.

\section{UN CASO DE DISEÑO EXPERIMENTAL COMO PRÁCTICA ARQUEOLÓGICA}

Cabe ahora avanzar hacia la siguiente pregunta: ¿por qué y cómo lo señalado encuentra, o podría encontrar, un lazo con aquello que llamamos diseño? Ciertamente, y como suele suceder, esta clase de in-

the French anthropologist Bruno Latour has drawn to redefine the scope of the social (Latour, 2008a) find in the machines, through Kittler and Ernst's media archeology, a specific actor which, with a strong agency, is therefore key to understanding social events. ${ }^{2}$

In short, let us then understand archeology, and specifically media archeology, as a method that allows us to investigate things in the field of the artificial, in order to trace their epistemic orders; in other words, to discover the specific knowledge that they transmit, process and store, thus delivering their agency, in turn, to the environments and actors they reach. Now, building on what has already been established, permit me to offset the notions of "thing" and "field of the artificial" into the idea of machines, expanded beyond the usual conception that places them in the field of the exclusively mechanical, in order to see them with a conceptual emphasis, as in writing machines, optical machines, phonographic machines and symbolic machines (Ernst \& cCAchannel, 2014). This will allow us to outline their agency capabilities and their actions of transmission, processing and storage of information and knowledge.

\section{A CASE OF EXPERIMENTAL DESIGN AS AN ARCHAEOLOGICAL PRACTICE}

It is time to move on to the following question: Why and how can the 
terrogante exige partir desde una disposición abierta respecto de este último concepto; esto es, liberarnos, al menos momentáneamente, de toda noción muy aguda respecto de qué es y no es el diseño. Tal ejercicio nos permitirá entrar en una reflexión —que por ahora llamaré teórica, pero que más adelante ya no lo será tanto- para vislumbrar la posibilidad de que, en lo contemporáneo, sean las máquinas las que estén diseñando nuestros contextos culturales, naturales y sociales y, por lo tanto, también la condición humana misma.

Dicha hipótesis encuentra en Kittler, en su noción de pattern recognition -donde él ve la esencia del diseño contemporáneo-, el soporte para levantarse, pues el diseño no habría logrado convertirse totalmente en un actor autónomo mientras - a través de máquinas escriturales, ópticas y fonográficas-los sentidos de la percepción humana fuesen aún requeridos para su activación; empero, el diseño sí habría obtenido su autonomía cuando, en tanto máquina simbólica - esto es, una máquina computarizada-, fue capaz de reconocer, codificar y procesar para nosotros, y por sí mismo, los patrones del entorno, para generar así una nueva forma de conciencia humana - pero esta vez, del tipo no-humana- (Kittler, 1993/2017, p. 150).

Esta hipótesis ve al diseño fuera, o más allá, de una profesión o de una práctica creativa en particular y, alternativamente, lo entiende como el campo en que se desarrollan los procesos de producción tecno-cultural y de conocimiento. Tal es, aquí, el diseño y su espacio.

aforementioned be linked with what we call design? Certainly, and as it often happens, this kind of questioning requires starting from an open disposition regarding this concept; that is, to free ourselves, at least momentarily, from any precise notion of what design is and is not. Such an exercise will allow us to enter into a reflection - which for now I will call theoretical, but that will not be so much later - in order to discover the possibility that, in the contemporary, it is the machines who are designing our cultural, natural and social contexts and, therefore, the human condition itself.

This hypothesis finds in Kittler, in his notion of pattern recognition - where he sees the essence of contemporary design - its foundation, as design would not have been able to become an autonomous actor while, through writing, optical and phonographic machines, the senses of human perception were still required for their activation. Design itself, however, would have obtained its autonomy when, as a symbolic machine, a computerized machine, it was able to recognize, encode and process for us and for itself, patterns of the environment, and to generate a new form of human consciousness - this time, of the non-human type (Kittler, 1993/2017, p. 150).

This hypothesis sees design outside, or beyond, a particular creative 
La paradoja surge, sin embargo, ante la posibilidad de notar que, en rigor, aquellas y aquellos que abracen los lenguajes de este diseño no harán sino aprender los lenguajes de dichos procesos epistémicos y de producción tecno-cultural; es decir, diseñadores que aprenderán los lenguajes de las máquinas diseñadoras.

Esta es precisamente la ruta que se busca recorrer con lo que denomino "diseño experimental como práctica arqueológica": indagar en los lenguajes de máquinas específicas —sean éstas escriturales, ópticas, fonográficas o simbólicas - para comprender los órdenes de conocimiento que ellas propician y, de esta forma, intentar vislumbrar cómo aquello se materializa en la cultura y en el espacio social. En suma, no se tratará más del clásico dictum del diseño que invita a detectar necesidades en la superficie de los acontecimientos para crear soluciones aplicadas en torno a ellas.

Por el contrario, se trata aquí, y en adelante, de recorrer los sedimentos de las culturas para encontrar allí las máquinas que estructuraron - y a veces siguen estructurando- espacios y períodos particulares; para luego, sumergiéndonos en sus lenguajes, trazar lo que han dicho, lo que han contado y, así, reconocer los órdenes de pensamiento que, desde ellas, determinan nuestros entendimientos de las cosas y los acontecimientos.

Este viaje - aún como perspectiva que se percibe con extrañeza y avanza todavía a contrapelo- lo hemos iniciado ya hace algún tiempo

profession or practice and, alternatively, understands it as the field in which the processes of techno-cultural production and knowledge are developed. Such as, here, design and its space. A possible paradox arises, however, in that strictly speaking, those who embrace the languages of this design will only learn the languages of these epistemic processes and of techno-cultural production; that is, designers who will learn the languages of the designing machines.

This is precisely the route to be followed with what I call 'experimental design as an archaeological practice': to investigate the languages of specific machines - whether writing, optical, phonographic or symbolic - in order to understand the orders of knowledge that they foster and, in this way, to try to discover how that materializes in culture and in the social space. In short, it will no longer be about the classic dictum of design that seeks to detect needs on the surface of events to create applied solutions around them.

On the contrary, it is about going through the sediments of cultures to find there the machines that structured (and sometimes continue to structure) spaces and specific periods; thereafter immersing ourselves in their languages, tracing what they have told us and what they have (re) counted, and finally recognizing the orders of thought that, from them, 
en la Universidad de Chile. En lo que sigue presentaré una porción de tal experiencia, comentando un proyecto que sirvió, además, de tesis de titulación en el contexto de la carrera de Diseño - siempre bajo la categoría que, al interior de ésta, se denomina proyecto experimental-, y donde contribuí como profesor guía. Se trata de Naturaleza Ex-novo (2015), de Adolfo Álvarez Dumont.

\section{Naturaleza ex-novo}

Tras la pregunta que intenta responder si acaso la naturaleza es diseñable; es decir, si aquel espacio que clásicamente se ha entendido como anterior a toda cultura es, más bien, un objeto del diseño, el proyecto de Adolfo Álvarez Dumont traza una trayectoria que lo lleva hasta el pasado decimonónico de Chile, para encontrar allí, en el período inicial de las repúblicas sudamericanas, las máquinas que dibujaron, más allá de su propia temporalidad, las formas y los márgenes de tal naturaleza. Para ello, el autor abraza la práctica arqueológica, primeramente, depositando su atención en el Atlas de la historia física y politica de Chile (1854) del naturalista francés Claudio Gay, para luego analizar los modos a través de los cuales se configuró un ordenamiento epistémico en torno a una noción de naturaleza, territorio y sociedad, que permitiría, luego, erigir las clasificaciones y representaciones políticas de un país.

Dicho atlas ha sido entendido aquí como máquina escritural; una

determine our understandings of things and events.

At the Universidad de Chile, we have already begun this journey, although still as a perspective that is perceived with suspicion and that tends to go against the grain. In what follows, I will present a portion of such experience, commenting on a project that also served as a thesis, which in the context of the Program of Design is labeled under the category of experimental project, and to which I contributed as supervisor. The project is Naturaleza Ex-novo (2015), by Adolfo Álvarez Dumont.

\section{Naturaleza Ex-novo (Nature Ex-Novo)}

On the face of the question that it seeks to answer, whether nature is designable (that is, if that space that has been classically understood as prior to any culture is, rather, an object of design), Adolfo Álvarez Dumont's project traces a trajectory that takes him to $19^{\text {th }}$ Century Chile, to find there, in the initial period of the South American republics, the machines that drew, beyond their own temporality, the forms and margins of such nature. In order to do this, the author embraces the archaeological practice; first, focusing on the Atlas de la historia física y política de Chile (1854) by the French naturalist Claude Gay, and then analyzing the modes through which an epistemic order was configured around a 
Figura 2: Láminas cartográfica, pictórica y de ilustración botánica. Fuente: Claudio Gay (1854). Atlas de la historia ‥ física y política de Chile. París, $\therefore$ Francia: Thunot, 1854 .

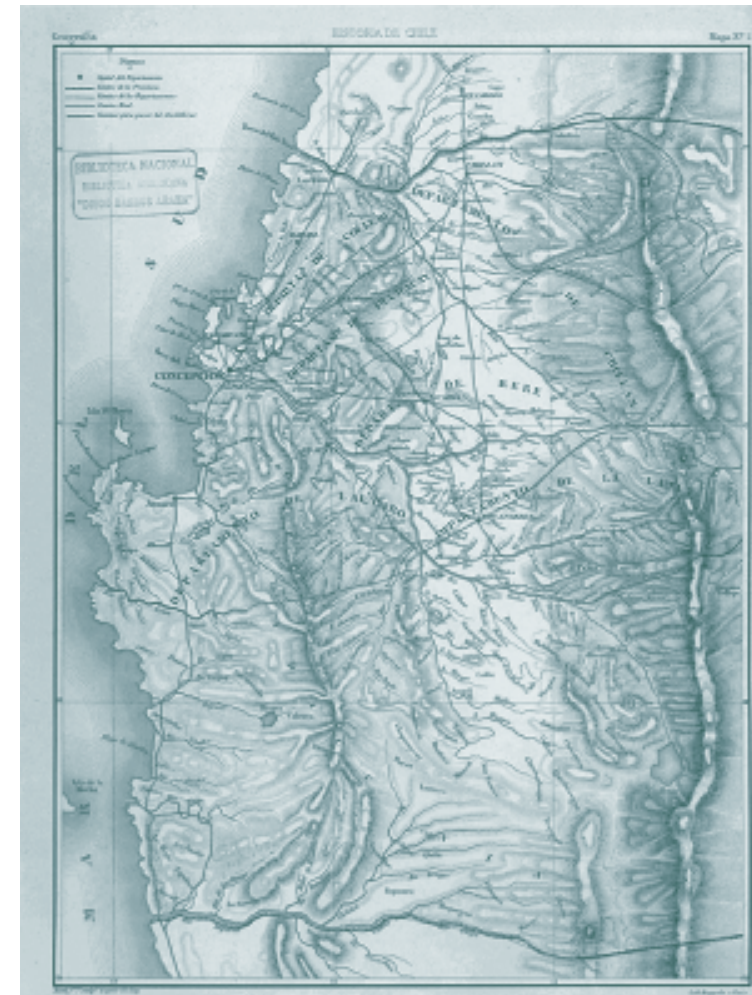

rnonseus od. cosciorsox

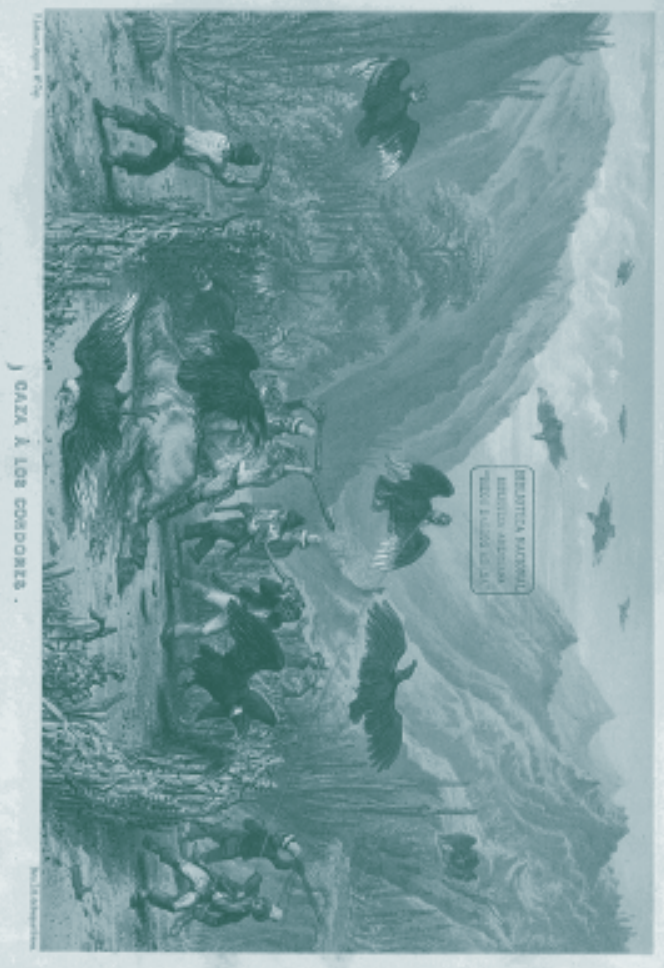

E. 
que, precisamente, escribió a través de lenguajes cartográficos, pictóricos y de ilustración botánica (Figura 2), no sólo las imágenes, sino, ante todo, los sistemas de reglas y de códigos que señalaron los límites de apertura y cierre de lo natural como fórmula de demarcación y materialización de una política para la construcción de un Imaginario de sociedad y nación. Así, por una parte, en los mapas e ilustraciones botánicas de Gay —en sus cuadrículas visibles o invisibles, en sus sistemas de coordenadas y escalas, en sus notaciones simbólicas-Álvarez Dumont percibe el surgimiento de un lenguaje técnico para una matematización de la naturaleza; mientras, por otra parte, en los retratos e imágenes pictóricas ve el relato del hombre, ese que viene a señalar que todo entorno, todo territorio, es todavía de su propiedad. En suma, dos lenguajes aparentemente contradictorios, pero que, al mismo tiempo, tal vez por lo mismo, permiten leer el atlas de Gay, además, como una máquina confrontacional (Gómez-Venegas \& Álvarez Dumont, 2017).

De ahí en adelante, el proyecto de Álvarez Dumont toma un giro especulativo (Dunne \& Raby, 2013); esta vez, preguntándose por la posibilidad de existencia de máquinas —escriturales o no, simbólicas o no- que (re)diseñen la naturaleza de un

notion of nature, territory and society, which would then allow the development of the classifications and political representations of a country.

The said atlas has been understood here as a writing machine that, precisely, wrote through cartographic, pictorial and botanical languages (Figure 2) not only the images, but, above all, the systems of rules and codes that determined the limits of the opening and closing of the natural, as a formula for demarcation and materialization of a policy for the construction of an Imaginary of society and nation. Thus, on the one hand, in the maps and botanical illustrations of Gay (in his visible or invisible grids, in his systems of coordinates and scales, and in his symbolic notations), Álvarez Dumont perceives the emergence of a technical language for a mathematization of nature; while, on the other hand, in the portraits and pictorial images he sees the story of Man, which show that all surroundings and all territories are still his property. In short, they are two apparently contradictory languages that, at the same time, and perhaps for the same reason, allow us to read Gay's atlas as a confrontational machine (Gómez-Venegas \& Álvarez Dumont, 2017). 
territorio, ahora con atención, también, a otras contextualizaciones y a otras exigencias propias de la contemporaneidad. En otras palabras, el autor se pregunta cómo y cuáles serían las máquinas capaces de (re) diseñar la naturaleza si se tomaran en cuenta los discursos y agencias tanto del naturalismo como de la ciencia moderna y de la corporativización de la economía, así como aquellos ocultos tras lo que se grita hoy, al margen de lo que dicen las hegemonías, en los centros de las sociedades.

Estos discursos, estas agencias, ingresan al proyecto cuando el autor observa algunas prácticas contemporáneas que, teniendo a la naturaleza como su asunto de interés (Latour, 2008b), activan espacios de

Figura 3: Proyecto Naturaleza Ex-Novo, de Adolfo Álvarez Dumont (2015). Fotografía: Pablo Marchant.

Figure 3: Naturaleza Ex-Novo Project, by Adolfo Ālvarez Dumont (2015). Photography: Pablo Marchant.

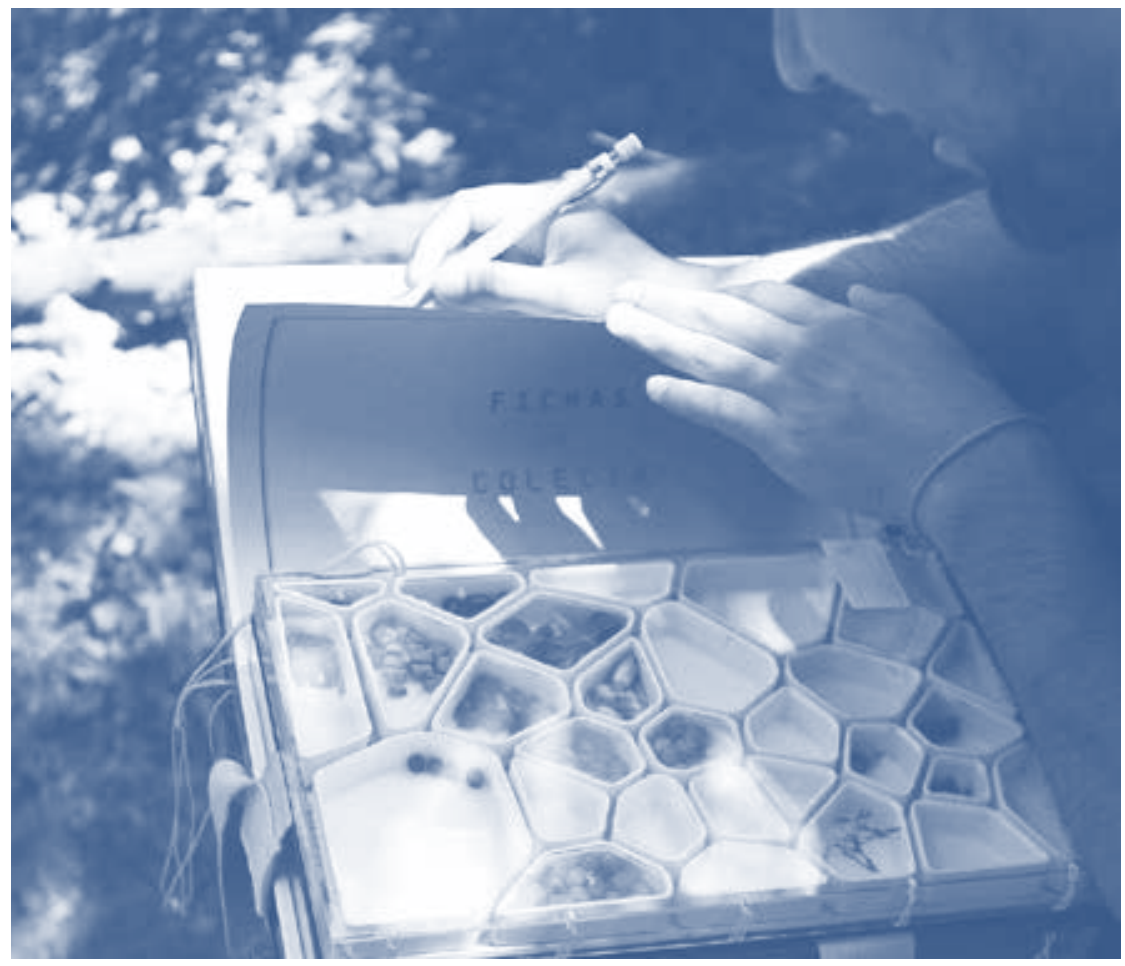

From then on, Álvarez Dumont's project takes a speculative turn (Dunne \& Raby, 2013), positing the possibility of the existence of machines - writing, symbolic or otherwise - that (re)design the nature of a territory, paying attention as well to other contextualizations and demands from contemporary times. In other words, the author asks how and what would be the machines capable of (re)designing nature if the discourses and agencies of both naturalism and modern science and the corporatization of the economy were taken into account, as well as those hidden behind what is being outwardly expressed today, regardless of what the hegemonies say in the centers of societies.

These discourses, these agencies, enter the project when the author 
confrontación para resituar el lugar de tal asunto más allá de los márgenes institucionales y corporativos que parecen querer envolverlo; a saber, huertos urbanos ciudadanos y, más particularmente, el activismo para el intercambio y resguardo de semillas. Álvarez Dumont se pregunta entonces sobre la hipotética posibilidad de existencia de máquinas que, atendiendo a los ordenamientos discursivos que dichas prácticas presentan, sean capaces de (re)diseñar una naturaleza ya sometida, por mucho - como muestra el atlas-, al registro y configuración de máquinas precedentes que, sin embargo, dada su relación de oposición con las prácticas antes mencionadas, vale aún la pena poner en cuestión.
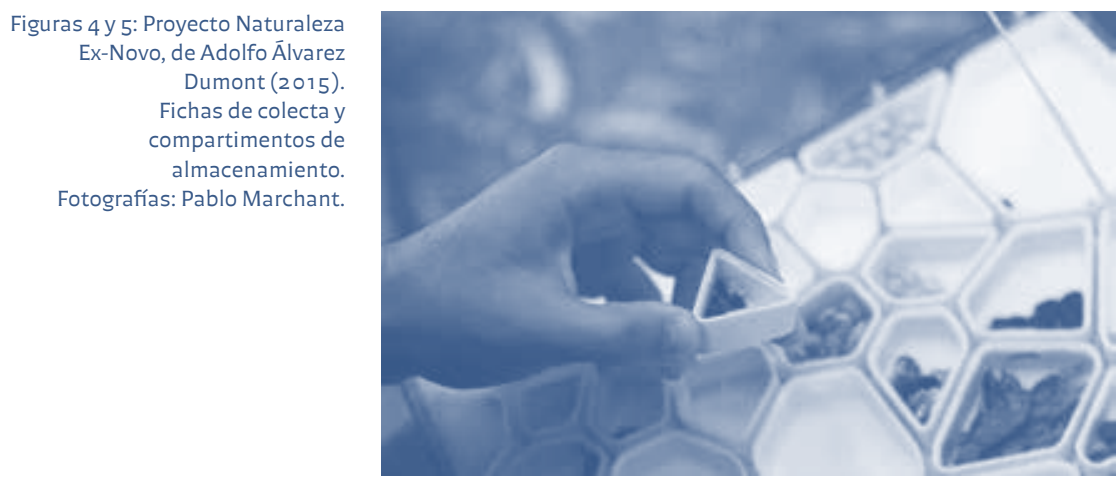

Figures 4 and 5: Naturaleza ExNovo Project, by Adolfo Ālvarez Dumont (2015). Collecting cards and storage compartments. Photographs: Pablo Marchant.

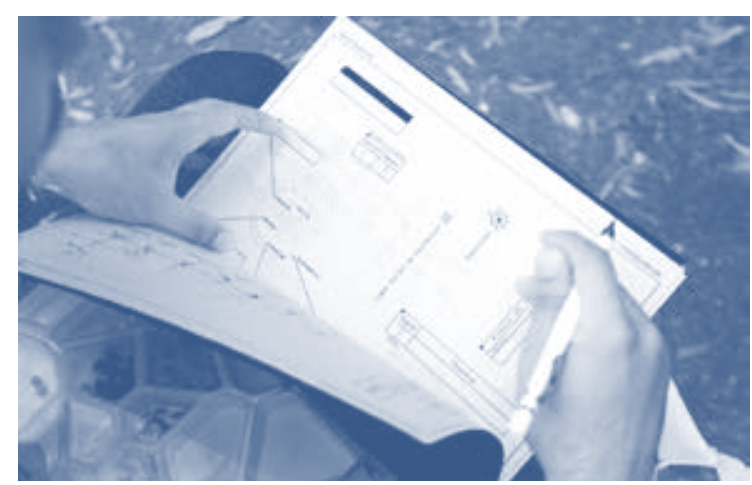

observes contemporary practices that, having nature as its matter of concern (Latour, 2008b), activate spaces of confrontation to bring the issue beyond the institutional and corporate margins that seem to want to limit it; namely, urban gardens and, more particularly, activism for the exchange and safeguarding of seeds. Álvarez Dumont then asks about the hypothetical possibility of the existence of machines that, based on the discursive orderings that these practices present, are capable of (re)designing a nature al ready heavily subjected to the registration and configuration of previous machines (as shown by the atlas) that, however, given their opposition to the aforementioned practices, is still worth questioning.

Then, looking in general at the naturalism of the $19^{\text {th }}$ Century, the 
Entonces, mirando en lo general hacia el naturalismo decimonónico, el autor diseña un aparato encuadernado cuyo objetivo, en términos amplios, es acompañar la recolección, el ordenamiento y el archivo de especímenes vegetales (Figura 3). Empero, en lo relativo a los métodos particulares para ejecutar cada una de esas tres acciones, el proyecto mira hacia órdenes epistémicos contemporáneos, los cuales, lejos de dibujar la naturaleza como un continuo, la leen - y escribencomo fragmentos de información para una procesualidad. Así, las fichas de colecta y los compartimentos de almacenamiento se acercan —aún no lo son- a la noción de máquinas simbólicas, pues a través de sus procedimientos lógicos parecen avanzar hacia el procesamiento de una naturaleza-dato - hacia un pattern recognition (Figuras 4 y 5) -

De este modo, y en contraste a las aproximaciones de un diseño social o de un diseño para la política (DiSalvo, 2012; Mouffe, 2007), las que, siempre en la superficie de los acontecimientos, verían probablemente en Naturaleza Ex-novo un producto para el activismo, Álvarez Dumont buscó, alternativamente, preguntar(se) si la naturaleza es un objeto diseñable y, con ello, interrogar cuáles fueron antes y cuáles serían después los lenguajes para tal diseño y, finalmente, cuáles son los modos, los sistemas de reglas, en que dichos lenguajes proceden y eventualmente podrían proceder sobre aquel objeto. En suma, una práctica de diseño experimental con vocación arqueológica.

author designs a bound apparatus whose objective, in broad terms, is to accompany the collection, sorting and archiving of plant specimens (Figure 3). However, regarding the particular methods used to execute each of these three actions, the project looks at contemporary epistemic orders, which, far from drawing nature as a continuum, read it - and write it - as fragments of information for processuality. Thus, the collecting cards and the storage compartments are close to - yet still are not - the notion of symbolic machines, because through their logical procedures they seem to advance towards the processing of a nature-data towards a pattern recognition (Figures 4 and 5).

In this way, and as opposed to the approximations of a social design or a design for politics (DiSalvo, 2012; Mouffe, 2007), which, on the surface of events, would probably see in Naturaleza Ex-novo a product for activism, Álvarez Dumont sought, alternatively, to ask if nature is a designable object. Thus, he questioned which languages were and will determine such design and, finally, which are the ways and the rule systems in which these languages do proceed and could eventually proceed on that object. In short, an experimental design practice with an archaeological vocation. 
Como he buscado clarificar a través del caso que ha guiado mi comentario, quienes quieran acercarse a la práctica de un diseño experimental en su vertiente arqueológica deberán atender a las siguientes tres cuestiones: a) que es preciso partir por seleccionar un objeto arqueológico que permita activar la problematización que guiará la indagación; b) que con él como centro, posteriormente se debe construir un mapa donde se ubiquen, de manera dispersa, una multiplicidad de otros objetos, para, ante todo, trazar los lazos que unen a unos y a otros, con el fin de conocer sus semejanzas y diferencias; c) que las preguntas que emerjan frente a todo ello deben avanzar hacia su materialización a través de un proceso de diseño experimental y especulativo que las reitere, idealmente esbozando o sugiriendo la presencia de las genealogías de objetos y asociaciones que señalan el recorrido de la indagación.

Probablemente convenga aquí, sin embargo, detenerse un instante para advertir algunos asuntos. Primero, que al decir objeto no se habla necesariamente de un artefacto palpable, sino del elemento depositario de nuestra atención investigativa, el cual, ante todo, debe tener la capacidad de hablarnos, desde las profundidades en las que se encuentra, sobre los órdenes epistémicos que resguarda; y que mientras éstos permiten y definen su existencia, influyen en, y por lo mismo también activan, la existencia de otros objetos que rodean al objeto arqueológico central.

\section{OUTLINING A METHOD}

As I have sought to clarify through the case that has guided my comments, those who want to approach the practice of an experimental design in its archaeological aspect should attend to the following three factors: a) that it is necessary to start by selecting an archaeological object to activate the problematization that will guide the inquiry; b) that focusing on it, a map should be constructed where, in a dispersed way, a multiplicity of other objects are located, in order to highlight the connections that unite one and the other, as well as to show their similarities and differences; $c$ ) that the questions that emerge from this should advance toward its materialization through a process of experimental and speculative design that reiterates them, ideally outlining or suggesting the presence of the genealogies of objects and associations that mark the course of the inquiry.

Here it will be convenient, however, to pause for a moment and issue a caution on a few issues. Firstly, by saying object we are not necessarily speaking of a palpable artifact, rather about the focus of our investigative attention, which, above all, must have the ability to speak, from whichever depths, about the epistemic orders that it protects; and that while these allow and define their existence, they influence, and there- 
Luego, como segunda advertencia, es fundamental ser capaces de discernir el carácter de aquel primer objeto en su condición de máquina; es decir, nuevamente, determinar si se trata de una máquina escritural, óptica, fonográfica o simbólica. Dicho discernimiento, por supuesto, no es un proceso espontáneo y, por el contrario, sólo se dará si es acompañado de sendas lecturas, cuidadosos estudios comparativos y análisis conceptuales muy bien informados.

Esto lleva a una tercera y última advertencia: que ninguna de las cuestiones metodológicas antes descritas - a, b y c-, son asuntos que puedan ser abordados y superados en unas pocas semanas, como tampoco en un par de meses. Por el contrario, cada uno de esos procesos debe entenderse en sí mismo como una investigación que requerirá del diseñador un alto grado de rigor intelectual, pensamiento crítico, capacidad creativa y compromiso productivo.

Cabe entonces, para cerrar este texto, preguntar por la relevancia y ubicación de esta aproximación en el contexto cultural y educativo actual. En tal sentido, debemos primero dirigir la atención a que, ya por décadas, las reflexiones sobre el porvenir social y cultural —que de modo sorprendente continúan, todavía, como dominio casi exclusivo de las artes más contemporáneas, de las humanidades más puras y de las ciencias sociales más sensibles con el devenir de los individuosno han cesado de preguntarse por el lugar que ocupan, como un solo conjunto, el pensamiento científico, las infraestructuras y las tecnolo-

fore also activate, the existence of other objects that surround the central archaeological object.

Then, as a second caution, it is fundamental to be able to discern the character of that first object in its condition as a machine; that is, determining whether it is a writing, optical, phonographic or symbolic machine. Such discernment, of course, is not a spontaneous process and, on the contrary, will only occur if it is accompanied by deep readings, careful comparative studies and well-informed conceptual analyzes.

This leads to a third and final caution: that none of the methodological issues described above $-a, b$ and $c-$ are issues that can be addressed and overcome in a few weeks, nor in a couple of months. On the contrary, each one of these processes must be understood in itself as a research that will require a high degree of intellectual rigor from the designer, as well as critical thinking, creative capacity and productive commitment.

Therefore, and to close this text, it is convenient to question the relevance and location of this approach in the current cultural and educational context. In this regard, we must first turn our attention to the fact that, for decades, reflections on the social and cultural future have been, and surprisingly still are, the almost exclusive domain of the most contemporary arts. The purest humanities, and the social sciences most sen- 
gías - esto es, el diseño - en el entendimiento de la condición humana.

Por cierto, ante tal escenario también ha sido sorprendente la falta de atención, de perspicacia y de sensibilidad que los diseñadores han manifestado frente a este asunto - más aún, cuando en aquel conjunto, frente a aquella condición, podría encontrarse, al fin, la esencia de eso que llamamos diseño-. En tiempos en que estas cuestiones aparecen del modo más evidente frente a nuestro juicio en nuestra vida social y política, haciéndose usuales los comentarios sobre cambio climático, mutaciones genéticas, experimentos farmacéuticos, bases de datos, algoritmos o inteligencia artificial, parece pertinente y justificable que el diseño cuente al menos con una rama que permita abandonar el carácter ignorante, irreflexivo y de falsa autosuficiencia que muchas veces lo representa. Sin embargo, esto requiere, ciertamente, un giro en la concepción del programa formativo de las así llamadas disciplinas del diseño, que permita instalar un perfil dedicado al pensamiento y la crítica cultural. Seguramente esto no podrá hacerse en cualquier lugar, pues las sociedades aún necesitarán diseñadores que se concentren sólo en configurar nuestras casas, nuestros medios de transporte y nuestras superficies de lectura. Tal vez, entonces, sea posible recurrir, a pesar de toda paradoja, a la vieja estructura universitaria para decir que serían las altas escuelas y los institutos politécnicos los espacios para abrigar a esos últimos diseñadores; que las universidades tecnológicas o de ciencias aplicadas serían aquellas donde se

sitive to the evolution of individuals, continue to enquire about the place occupied, as a single set, by scientific thinking, infrastructures and technologies - that is to say, design - in understanding the human condition.

It is worth mentioning that, considering such a scenario, the lack of attention, insight and sensitivity that designers have expressed regarding this issue has been surprising; even more so, when in that group, faced with that condition, one could find, at last, the very essence of what we call design. At a time when these issues appear most obviously in the face of our judgment in our social and political life, with our daily commentaries about climate change, genetic mutations, pharmaceutical experiments, databases, algorithms or artificial intelligence, it seems pertinent and justifiable that design has at least one branch that allows it to abandon the ignorant, unreflective and falsely self-sufficient character by which it is often represented. However, this certainly requires a change in the design of the curriculum of the so-called disciplines of design, in order to allow a new profile dedicated to thought and cultural critique. This surely cannot be done just anywhere, because societies will still need designers who concentrate only on configuring our homes, our means of transport and our reading surfaces. Perhaps, then, it is possible to resort, in spite of the paradoxes, to the old university structure to 
3 Ver Antipán Olate, 2015 y Figueroa Gutiérrez, 2016. sigan perfeccionando e inventando las tecnologías y sus nuevos procedimientos; $y$, finalmente, que las universidades propiamente tales serían el lugar donde - abandonando toda pretensión y vocación profesional- pueda desarrollarse el diseño como práctica arqueológica.

Esto no sucederá - al menos no en Chile- en el futuro próximo. En el intertanto, aquellos que busquen todavía abrazar estos lenguajes indagatorios sabrán que deberán hacerlo sólo como iniciativa individual — como sucediera en el caso antes comentado y en otros pocos que he podido acompañar ${ }^{3}$ - . Para el resto, parafraseando nuevamente a Kittler - tal como él lo hiciera a su vez con Lacan-, queda aún el baile, el jazz y la libido. Al menos hasta que las máquinas tomen el control total (Kittler, 1993/2017, p. 155).D

say that colleges and polytechnic institutes would be the spaces to host these latter designers; that the technological or applied science universities would be those where they continue to perfect and invent the technologies and their new procedures; and, finally, that the universities themselves would be the place where, abandoning all professional pretension and vocation, design could be developed as an archaeological practice.

This will not happen - at least not in Chile - in the near future. In the meantime, those who still seek to embrace these questioning languages will know that they should do so only as an individual initiative, as in the aforementioned case and in a few others that I have referred to. ${ }^{3}$ For the rest, and paraphrasing Kittler once again, as he himself did with Lacan, there is still dancing, jazz and libido. At least, until the machines take full control (Kittler, 1993/2017, p. 155). (1) 
Álvarez dumont, A. (2015). Naturaleza Ex-novo: Diseño de aparato encuadernado para mediar en la colección, archivo y representación botánica fuera de los márgenes institucionales (Unpublished undergraduate thesis). Universidad de Chile, Santiago, Chile. Retrieved from http://repositorio.uchile.cl/handle/2250/136813

ANTIPÁN OLATE, M. (2015). Visualizar el Illkun. Proyecto experimental que busca reflexionar y poner en discusión el concepto de pantalla en relación con memorias en conflicto (Unpublished undergraduate thesis). Universidad de Chile, Santiago, Chile. Retrieved from http://repositorio.uchile.cl/handle/2250/130040

DISAlvo, C. (2012). Adversarial design. Cambridge, MA: The MIT Press.

DUNNE, A., \& RABY, F. (2013). Speculative everything: Design, fiction, and social dreaming. Cambridge, MA: The MIT Press.

ERNST, W. (2012). Digital memory and the archive. Minneapolis, MN: The Minnesota University Press.

ERNST, W \& CCACHANNEL (Director) (2014). Digital Media Archaeology: Archive, Museum and Sonicity [Video]. Retrieved from www.youtube.com/watch?v=f_ GsDqKuof 8\&feature=youtu.be

ERNST, W. (2016). "Electrified voices": Non-human Agencies of Socio-Cultural Memory. In ı. Blom, T. Lundemo, \& E. Røssaak (Eds.), Memory in motion: Archives, technology, and the social (pp.41-59). Amsterdam, Netherlands: Amsterdam University Press.

FIGUEROA GUTIÉRREZ, A. (2016). Victoria de septiembre. Proyecto de diseño especulativo que busca poner en discusión el desarrollo de las políticas tecnológicas en el gobierno de la Unidad Popular. 1970-1973 (Unpublished undergraduate thesis). Universidad de Chile, Santiago, Chile. Retrieved from http://repositorio. uchile.cl/handle/2250/139585

FOU CAULT, M. (2008). Las palabras y las cosas: una arqueología de las ciencias humanas. Buenos Aires, Argentina: Siglo xxı.

FOUCAULT, M. (2010). La arqueología del saber. D.F., México: Siglo xxı.

GómeZ-VEnEGAS, D, \& ÁlvAREZ dumonT, A. (2017). Naturaleza Ex-novo: aparatos agonistas para el rediseño de la naturaleza y sus márgenes en Chile. Kepes, 14(16), 265-289.

KITTLER, F. (2017). El mundo de los simbólico - un mundo de las máquinas. Canal, Cuadernos de Estudios Mediales y Visuales (1), 122-157.

KITTLER, F. (1992). Discourse networks, $1800 / 1900$.

Stanford, CA: Stanford University Press.
LACAN, J. (2008). El seminario de Jacques Lacan: los escritos técnicos de Freud: 1953-1954: Libro 1. Barcelona, Spain: Paidos.

LATOUR, B. (2008a). Reensamblar lo social: una introducción a la teoría del actor-red. Buenos Aires, Argentina: Manantial.

LATour, B. (2008b). A Cautious Prometheus? A Few Steps Toward a Philosophy of Design. In F. Hackne, J. Glynne, \& v. Minto (Eds.), Networks of design: Proceedings of the 2008 Annual International Conference of the Design History Society (UK) University College Falmouth, September 3-6. Boca Ratón, FL: HAL CCSD Universal Publishers.

mouffe, C. (2007). En torno a lo político. Buenos Aires, Argentina: Fondo de Cultura Económica.

ZERENÉ, J. (2017). Arqueologías mediales: un diagnóstico de Jussi Parikka. Canal, Cuadernos de Estudios Mediales y Visuales (1), 90-120. 